\title{
ヒ素，セレンおよび臭素の $\mathbf{X}$ 線 $\mathbf{K}$ 吸収スペクトルの微細構造 ${ }^{1)}$
}

(1975 年 9 月 5 日 受 理)

岩 附 正 明 - 深 沢 力*

化学分析のさいの試料の前処理を決定したりするのに必要なヒ素, セレンおよび臭素の存在状態を明 らかにする方法を開発する目的で，トパズ分光結晶を装着したX線回折計を用いて，単体や各種化合物 中のこれらの元素の $\mathrm{X}$ 線 $\mathrm{K}$ 吸収スペクトルを測定した。その結果, このような場合の状態分析に応用で きる知見を得た。

いずれの元素についても原子価が正の酸化物や硫化物では, 吸収端の短波長側にいちじるしい微細構 造が認められた。一方, 原子価が負または０のものでは，一般に微細構造の起伏が小さい。吸収端や各 吸収ピークの位置は結合原子が同じとき，高原子価ほど短波長側へシフトする傾向があったが，結合原 子が異なるとさは，同じ原子価でもシフトの程度が異なった。同一物質の粉末試料と溶液試料では微細 構造の各点の位置に系統的変化は認められなかったが, 吸収端に近い方から数えて1番目の吸収ピーク と 3 番目の吸収ピークの $\mathrm{K}$ 殼光電吸収係数の比は粉末試料よりも水溶液やエタノール溶液試料で大きく なった。

\section{1 粕言}

当研究室では高純度セレン中の微量ハロゲンや高純度硫黄中の 微量セレンの陰イオン交換分離の研究を行なっているが，この場 合, 試料を過酸化水素水その他に溶解したのち，イオン交換分離 を行なら。このような場合，セレンの溶存状態は分離に深いかか わりあいをすつ。また，七素あるいはセレンを含む合金を酸化性 の酸で溶解したり，七素，七レンあるいは臭素を含む岩石または ガラスをアルカリ融解したのち，これらの元素や他の元素を定量 することがある。そのような場合に拈いても，これらの元素の存 在状態は正しい分析操作を行ならら光深いかかわりあいがあ る。しかしながらこのような場合のこれらの元素の存在状態を 決定する方法についての十分な研究は注とんどない。一方，X線 吸収スペクトルは吸収端より短波長側で，しばしば微細構造が認 められこれが化学結合の状態などによって恋化する。しかしな がら，状態分析に応用できるよらな，これらの元素のX線吸収ス ペクトルに関する研究は見あたらない。したがって，まず単体や 各種化合物中のこれらの元素の $\mathrm{K}$ 吸収スペクトルを測定して，そ れらの存在状態と吸収スペクトルとの関連性を検討した。その結 果, 上に述べたらな場合のこれらの元素の状熊分析に応用でき るよらな知見を得たので，まずこれについて報告する。

\section{2 実験}

\section{1 装置と試料}

吸収スペクトルの測定には理学電機製自記 X線回折計（封入型 比例計数管装着）をつぎのようにして用いた。すなわち，試料は 特記しないかぎり発散スリットの直後に置き，また試料を通過し

1）この報文を“ $\mathrm{X}$ 線吸収スペクトルによる状態分析に関する 研究(第 1 報)”とする.

* 山梨大学工学部応用化学科, 400 甲府市武田
たX線を分光するため，ゴニオメーターの中心（回折実験のさい の試料位置) にトパズ単結晶 $(2 d=2.795 \AA$, ケイ光 X線分析用, $70 \times 20 \times 4 \mathrm{~mm}$ ) を置いた。

試料としては高純度セレンと合成単結晶片を粉砝した GaAs の ほかは試薬を用いた。

\section{2 測定方法}

粉末試料はメノウ乳バチで約 300 メッシュ以下に粉砕したのち, 試料と同体積程度の白色ワセリンと練り, 厚さ $6 \mu$ のマイラー膜 にできるかきりり均一に塗り，これを回折実験用 $\beta$ てィルター・ ホルダー（フィルターを取り除いたもの）にセロテープでとめて 測定に供した。溶液試料は図 1 のマイラー・セル（自作）に，ま たブロモホルムと臭素は図 2 のテフロン・セル（自作）に入れて 湘定に供した。測定は特記しないかぎり表 1 の条件で, $0.01^{\circ}$ $(2 \theta)$ 間隔で定時法（40秒）により行なった。

測定値の再現性を調べるため，金属セレン粉末試料の Se K 吸収端をつづけて 5 回（1 回の所要時間は約 30 分）測定したと ころ, 吸収端角度 $(2 \theta)$ の標準偏差は約 $0.0015^{\circ}$ (約 $0.5 \mathrm{eV}$ ) であった。

なお，管球を装着しなおしたときや測定日が変わったとき（後 者では振動によると思われるが $0.005^{\circ}$ 程度のずれが生じること があった）の角度のずれはつぎのように補正した。すなわち， $\mathrm{Se} \mathrm{K}$ とBr K 吸収スペクトルについては，それぞれ測定日ごと

Table 1 Experimental conditions

$\mathrm{X}$-ray tube

Mo Tube voltage $(\mathrm{kV})$

$\left\{\begin{array}{l}\text { for } \mathrm{Se}, \mathrm{Br} \\ \text { for As }\end{array}\right.$

25

23

Tube current $(\mathrm{mA})$

25

Divergence \& scatter slit $\left({ }^{\circ}\right)$

Receiving slit(mm) 


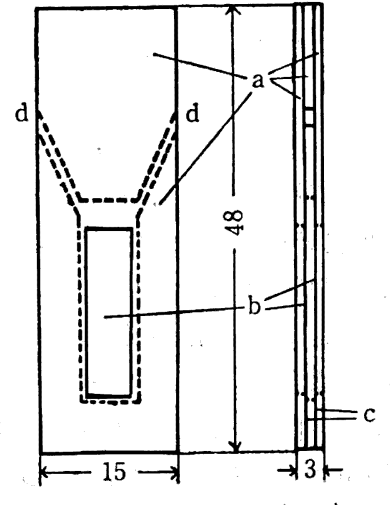

$(\mathrm{mm})$

Fig. 1 Mylar-window cell for solution samples a : Poly (vinyl chloride).

b : Mylar film $(6 \mu)$.

c : Sticked with epoxy resin adhesive.

$\mathrm{d}$ : Sample inlet (After the sample was charged, these inlets were sealed with plasticine).

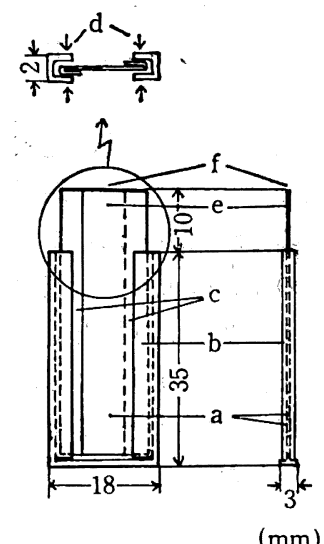

Fig. 2 Teflon-window cell for bromine and bromoform a : Teflon film $(0.11 \mathrm{~mm})$.

$\mathrm{b}$ : Aluminum frame.

c : Folded parts of Teflon film.

$\mathrm{d}$ : Pressed strongly with pincers and a vise.

e : After the sample was charged, this part was turned down and nipped with a paper holder.

f : Sample inlet.

に外標準として金属セレン試料を用い Se K 吸収端角度で，また は $\mathrm{KBr}$ 粉末試料を用い $\mathrm{Br} \mathrm{K}$ 吸収端角度で補正した。また，As $\mathrm{K}$ 吸収スペクトルについては入射X線自体に認められた WLr 4 ピ ークの角度で補正した。

\section{3 結果之考察}

\section{1 酸化物と硫化物の吸収スペクトルの特徽}

本研究で測定した酸化物と硫化物の吸収スペクトルは，いずれ る図3で示されるようないちじるしい微細構造を示した。この微 細構造の特徵は第 1 系列遷移元素の酸化物について従来報告され たもの2)と一致している。ここで，Kは吸収差が $1 / 2$ になる角度

2) E.W. White, H. A. McKinstry, "Advances in X-Ray Analysis”, Vol. 9, Plenum Press, New York, N. Y. (1966)p. 376.

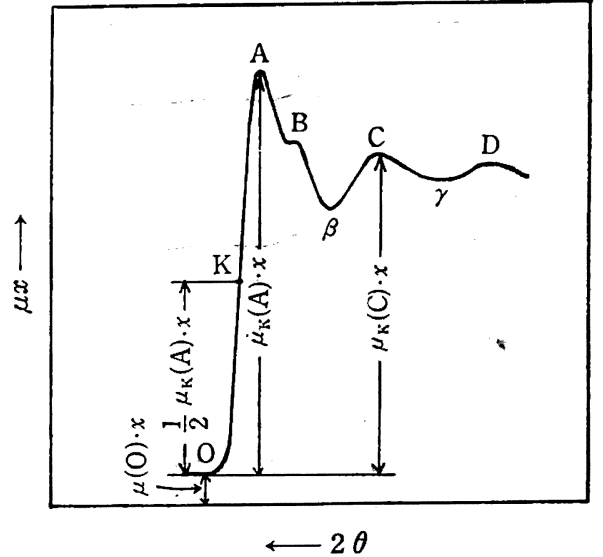

Fig. 3 Schematic absorption curve of oxide or sulfide measured

で表わした K吸収端位置である。また，A， B， C，D吸収ピー クの山の位置を, $\beta, \gamma$ は谷の位置を, Oは吸収端より高角度（長 波長，低エネルギー）側の吸収が増大し始める位置を示す。ただ し，Bは試料によっては認められなかったるのもありまた認め られたものでも一般に山とはならず，Aの肩として現われた。ま た，第 1 吸収ピークA と第 3 吸収ピークCの高さの比が試料によ って変化したので, これを特性づけるため,これらの点での測定 元素の $\mathrm{K}$ 殻光電吸収係数の比 $\mu_{\mathrm{K}}(\mathrm{A}) / \mu_{\mathrm{K}}$ (C) を求めた ${ }^{3)}$ 。なお, 酸化物と硫化物以外でも, 微細構造が認められたものは山や谷の 位置を同様の記号で示した。

\section{2 試料厚さその他測定条件の影響}

吸収スペクトルに対する試料厚さの影響については，従来，な

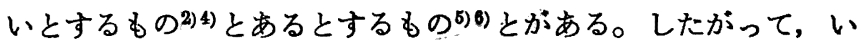
ちじるしい微細構造が認められた $\mathrm{NaBrO}_{3}$ 粉末試料の $\mathrm{Br} \mathrm{K}$ 吸 収スペクトルについて，この影響を検討した。ただしこの実験 においてのみ, $\mathrm{NaBrO}_{3}$ 試料のほか, 一定厚さの金属セレン粉末 試料を発散スリットの直後につけ、ゴニオメーターを $1 / 8^{\circ} / \mathrm{min}$ で走査して, Se K 吸収端と Br K 吸収スペクトルをチャートに

3）これはつきのようにして求めることができる.すなわち, 波長 $\lambda$ に打ける試料の線吸収係数 $\mu(\lambda)$ を測定元素のK殼 光電吸収による線吸収係数 $\mu_{\mathbf{K}}(\lambda)$ とそれ以外による線吸収 係数 $\mu^{\prime}(\lambda)$ にわけると，

$$
\mu(\lambda)=\mu_{\mathbf{K}}(\lambda)+\mu^{\prime}(\lambda)
$$

いま， $\mathrm{O}$ 点は $\mathrm{K}$ 吸収端より長波長側にあるから，

$$
\mu_{\mathrm{K}}(0)=0
$$

また， $0, A$ およびCの 3 点では波長が近いから，これら の点での $\mathrm{K}$ 壳光電吸収以外による線吸収係数壮それぞれ等 しいと見なせる。すなわち，

$$
\mu(0)=\mu^{\prime}(0) \simeq \mu^{\prime}(\mathrm{A}) \simeq \mu^{\prime}(\mathrm{C})
$$

したがって，試料厚さを $x$ とすると，

$$
\frac{\mu_{\mathrm{K}}(\mathrm{A})}{\mu_{\mathrm{K}}(\mathrm{C})}=\frac{\mu(\mathrm{A}) \cdot x-\mu^{\prime}(\mathrm{A}) \cdot x}{\mu(\mathrm{C}) \cdot x-\mu^{\prime}(\mathrm{C}) \cdot x} \simeq \frac{\mu(\mathrm{A}) \cdot x-\mu(0) \cdot x}{\mu(\mathrm{C}) \cdot x-\mu(0) \cdot x}
$$

この(1)式の右辺は実験データから得られる值であり，こ れから、 $\mu_{\mathrm{K}}(\mathrm{A}) / \mu_{\mathrm{K}}(\mathrm{C})$ を求めることができる.

4) H. Kubo, H. Nakamori, K. Tsutsumi, Jap. J. Appl. Phys., 9, $1372(1970)$.

5) L. G. Parratt, C. F. Hempstead, E. L. Jossen, Phys. Rev., 105, 1228(1957).

6）岡本伸和，小林昭光，梶川正雄，長谷川恵之，分析化学， 14, 896(1965). 


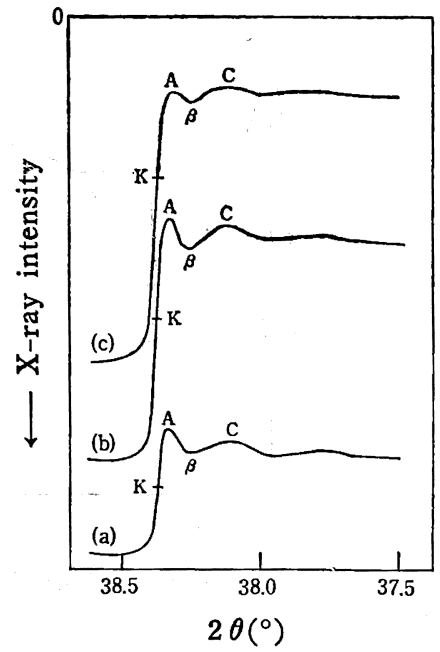

Fig. 4 Effect of sample thickness on $\mathrm{Br} \mathrm{K}$ absorption spectrum of $\mathrm{NaBrO}_{3}$ powder

Sample thickness-

(a) : $10 \mu$, (b ) : $33 \mu$, (c ) $: 74 \mu$

Receiving slit : $0.15 \mathrm{~mm}$

Sample position : Before receiving slit

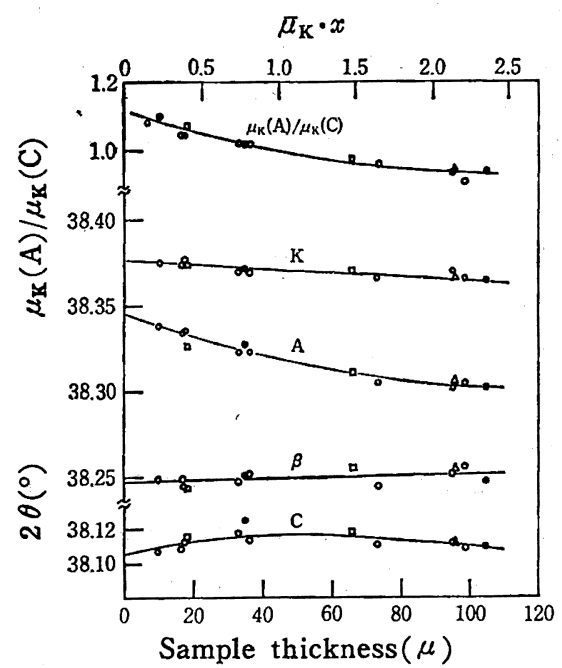

Fig. 5 Relationship between thickness and fine structures of $\mathrm{Br} \mathrm{K}$ absorption spectrum of $\mathrm{NaBrO}_{3}$ powder

Receiving slit Sample position

\begin{tabular}{lll}
\hline $\mathrm{O}:$ & $0.15 \mathrm{~mm}$ & Before receiving slit \\
$:$ & $0.05 \mathrm{~mm}$ & Before receiving slit \\
$\triangle:$ & $0.15 \mathrm{~mm}$ & After scatter slit \\
$\square:$ & $0.15 \mathrm{~mm}$ & After divergence slit
\end{tabular}

記録させて測定し, Se K 吸収端位置からゴニオメーター角度の 微小なずれを補正した。測定した吸収スペクトルの一部を図 4 に 示した。また, 試料厚さと微細構造の各点の位置ならびに $\mu_{\mathrm{K}}(\mathrm{A}) /$ $\mu_{\mathrm{K}}(\mathrm{C})$ の值との関係を図 5 亿示した。試料厚さ $x$ はつぎのよう にして求めた。すなわち，まず $\mathrm{Br} \mathrm{K}$ 吸収端での質量吸收係数 の差を文献》の值（微細構造をもたない）をプロットして求め $\left(126 \mathrm{~cm}^{2} / \mathrm{g}\right)$, これに $\mathrm{NaBrO}_{3}$ の密度 $\left(3.34 \mathrm{~g} / \mathrm{cm}^{3}\right)$ と $\mathrm{NaBrO}_{3}$

7) H. J. Milledge, "International Tables for X-ray Crystallography", Vol. III, Edited by C. H. MacGillavry, G. D. Rieck, Kynoch Press, Birmingham, England (1968) p. 176.
中の $\mathrm{Br}$ の重量分率（0.530）を掛けて, $\mathrm{NaBrO}_{3}$ の $\mathrm{Br} \mathrm{K}$ 光電四 収による線吸収係数（平均） $\mu_{\mathrm{K}}$ を求めた $\left(223 \mathrm{~cm}^{-1}\right)$ 。一方, 各 試料の $\mathrm{Br} \mathrm{K}$ 吸収端での $\mu x$ の差(低角度側での起伏は平均した) から $\mu_{\mathrm{K}} x$ を求め, これを上述の $\mu_{\mathrm{K}}$ で割って $x$ を得た。図 4,5 から明らかなよらに試料厚さの影響が認められた。試料が厚くな ると，とくに第 1 四収ピークAの高さが大きく減少し，またその 角度がいくらか低角度側へずれた。しかし，K， $\beta, C$ などへの影 響は比較的小さかった。試料厚さが吸収スペクトルに影響を与兄 る原因を Parrattら゙)はスペクトロメーターの “spectral window”に求めたが, 本研究で受光スリットの幅を变光た範团 $(0.15 \mathrm{~mm}$ と $0.05 \mathrm{~mm})$ では有意差が認められなかった。し かし，薄い試料で得られるスペクトルの方か，その物質本来のス ペクトルに近いと考觉られる。したがって，正確なスペクトルを 得るためには試料厚さを薄くする必要がある。図 5 の結果によれ ば, $\mu_{\mathrm{K}}(\mathrm{A}) / \mu_{\mathrm{K}}(\mathrm{C})$ の厚さ 0 に外插した值からのずれを $5 \%$ 以内 に抑觉るためには， $\bar{\mu}_{\mathrm{K}} x$ を 0.4 以下にする必要がある。一方， あまり薄すぎては測定精度が悪くなる。本研究の測定条件で，吸 収係数の $10 \%$ の変化を $95 \%$ の確率で判別できるためには, 測定 強度の統計变動から考えて $\mu_{\mathrm{K}} x$ が 0.12 以上である必要があっ た。したがって, 本研究では $\mu_{\mathrm{K}} x$ が $0.12 \sim 0.4$ となるように試 料厚さを調整した。

また, 試料位置を受光スリット直前, 発散スリット直後および 散乱スリット直後と变えて，その影響を調べたが，図 5 のように 微細構造に有意差は認められなかった。ここでは測定中に試料が 移動しないため, 試料のずれによる測定値の変動が生じにくいこ とから，試料位置を発散スリット直後とした。

なお，X線管電王はX線強度のうえからは高い方がよが, 分 光結晶による 2 次回折線の影響を避けるため, 各元素の $\mathrm{K}$ 線の臨 界励起電圧の 2 倍以下とした。

\section{3 吸収スペクトルと存在状態との関連性}

測定した吸収スペクトルの一部を図 $6 〜 13$ に示した。また, 微細構造の各点の単体の $\mathrm{K}$ 吸收端からのエネルギー差と $\mu_{\mathrm{K}}(\mathrm{A}) /$

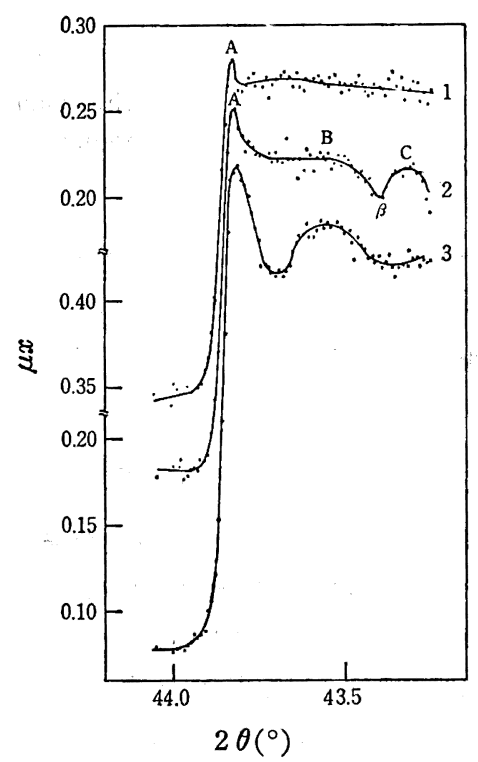

Fig. 6 As $\mathrm{K}$ absorption spectra for arsenic, GaAs and $\mathrm{As}_{2} \mathrm{O}_{3}$

$1:$ Arsenic, $2: \mathrm{GaAs}, 3: \mathrm{As}_{2} \mathrm{O}_{3}$ 


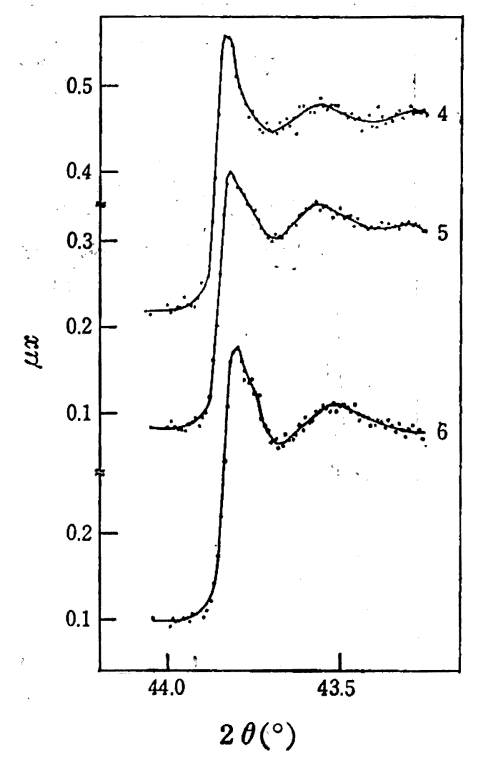

Fig. 7 As $\mathrm{K}$ absorption spectra for $\mathrm{NaAsO}_{2}$ and $\mathrm{Na}_{2} \mathrm{HAs}_{4} \cdot 7 \mathrm{H}_{2} \mathrm{O}$

$4: \mathrm{NaAsO}_{2}$ (aqueous soln.), $5: \mathrm{NaAsO}_{2}$ (powder), $6: \mathrm{Na}_{2} \mathrm{HAsO}_{4} \cdot 7 \mathrm{H}_{2} \mathrm{O}$

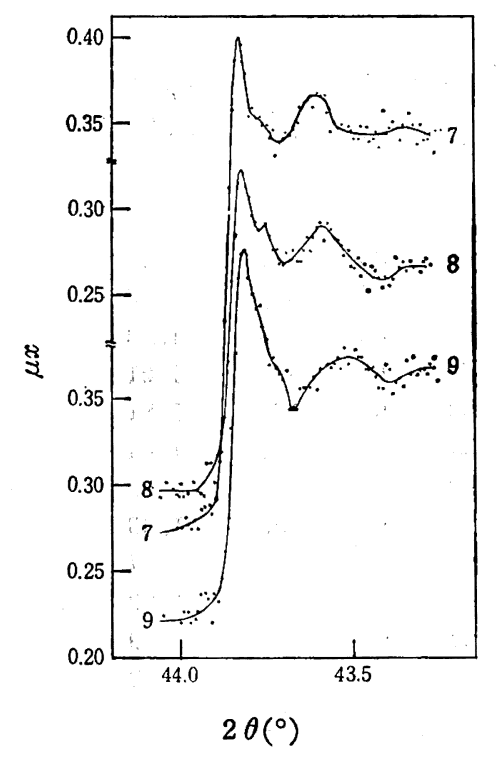

Fig. 8 As $\mathrm{K}$ absorption spectra for $\mathrm{As}_{2} \mathrm{~S}_{3}$, $\left[\mathrm{AsS}_{4}\right]^{3-}$ and $\mathrm{Na}_{2} \mathrm{HAsO}_{4}$ aqueous solution

$7: \mathrm{As}_{2} \mathrm{~S}_{3}, 8:\left[\mathrm{AsS}_{4}\right]^{3-}, 9: \mathrm{Na}_{2} \mathrm{HAsO}_{4}$ (aqueous soln.)

$\mu_{\mathrm{K}}(\mathrm{C})$ の值を表 2 〜 に示した。これらの結果からつぎのこと がわかった。

1）いずれの元素についても，第 1 系列遷移元素の場合2)688) と 類似して，原子価が正のもの（ここでは酸化物之硫化物）では吸 収端の短波長側にいちじるしい䍀細構造が認められ，一方，0の すのでは微細構造の起伏が小さかった。また, 原子価が負のもの は，第 1 系列遷移元素では測定されていないが，七素，センンお よびとくに具素では原子価が正のものにくらべて微細構造の起伏 が小さいことがわかった。硫黄や塩素については原子価が負また

8) R.A. Van Nordstrand, "Non-Crystalline Solid", John Wiley and Sons, Inc., New York, N. Y. (1968)p. 168.

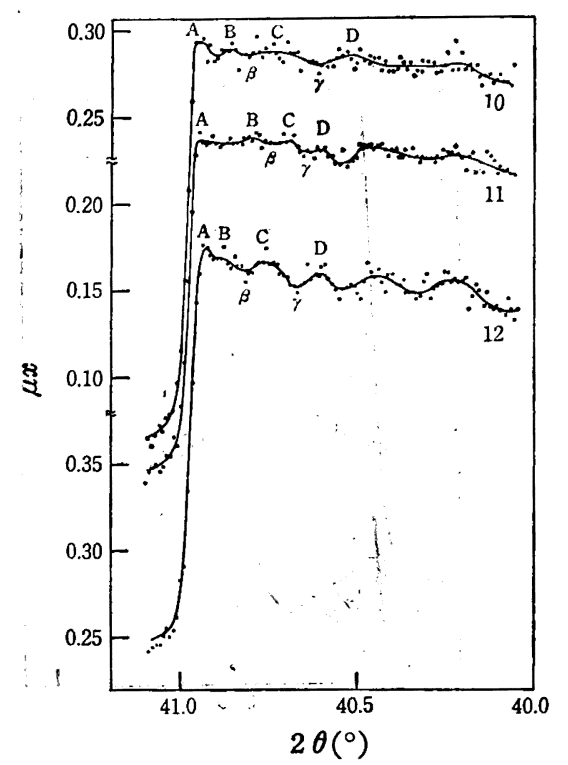

Fig. 9. Se $\mathrm{K}$ absorption spectra for selenium and $\mathrm{CdSe}$ 10 : Selenium(red), $11:$ Selenium(metallic), $12:$ CdSe

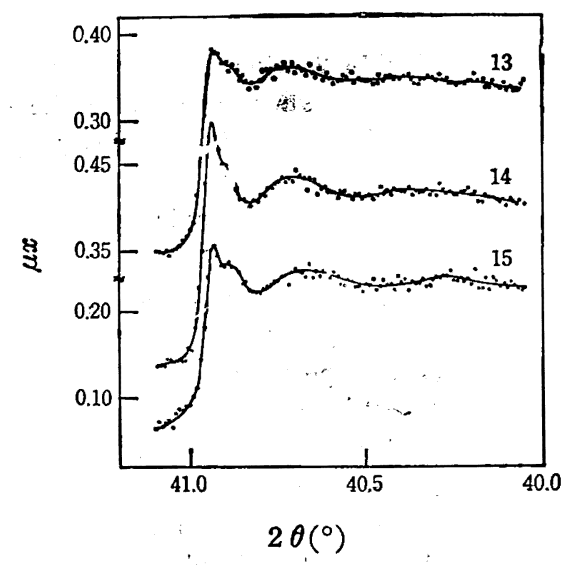

Fig. 10 Se $\mathrm{K}$ absorption spectra for powders of $\mathrm{H}_{2} \mathrm{SeO}_{3}$, $\mathrm{K}_{2} \mathrm{SeO}_{3}$ and $\mathrm{Na}_{2} \mathrm{SeO}_{4}$

$13: \mathrm{H}_{2} \mathrm{SeO}_{3}, 14: \mathrm{K}_{2} \mathrm{SeO}_{3}, 15: \mathrm{Na}_{2} \mathrm{SeO}_{4}$

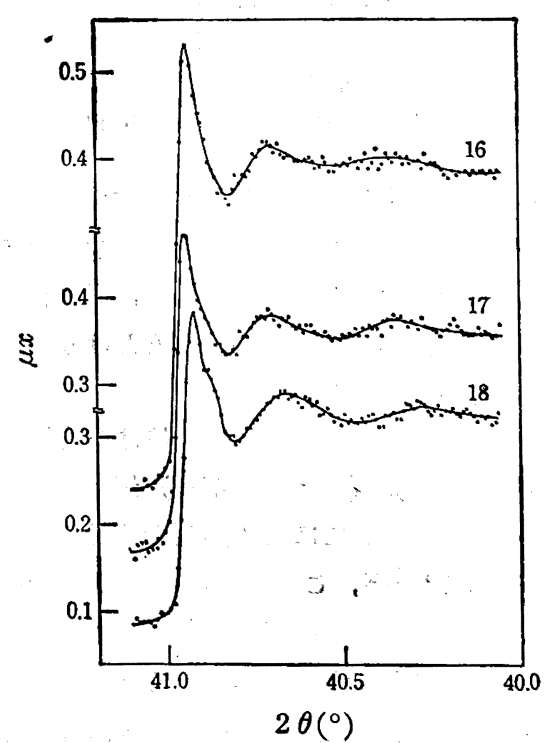

Fig. 11 Se $\mathrm{K}$ absorption spectra for aqueous solutions of $\mathrm{H}_{2} \mathrm{SeO}_{3}, \mathrm{~K}_{2} \mathrm{SeO}_{3}$ and $\mathrm{Na}_{2} \mathrm{SeO}_{4}$

$.16: \mathrm{H}_{2} \mathrm{SeO}_{3}, 17: \mathrm{K}_{2} \mathrm{SeO}_{3}, 18: \mathrm{Na}_{2} \mathrm{SeO}_{4}$ 


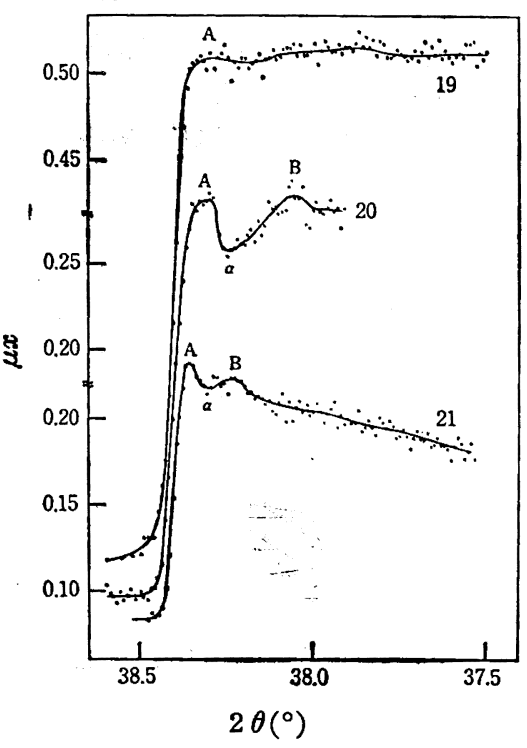

Fig. $12 \mathrm{Br} \mathrm{K}$ absorption spectra for bromine, bromoform and $\mathrm{NH}_{4} \mathrm{Br}$

$19: \mathrm{NH}_{4} \mathrm{Br}, 20:$ Bromine, $21:$ Bromoform

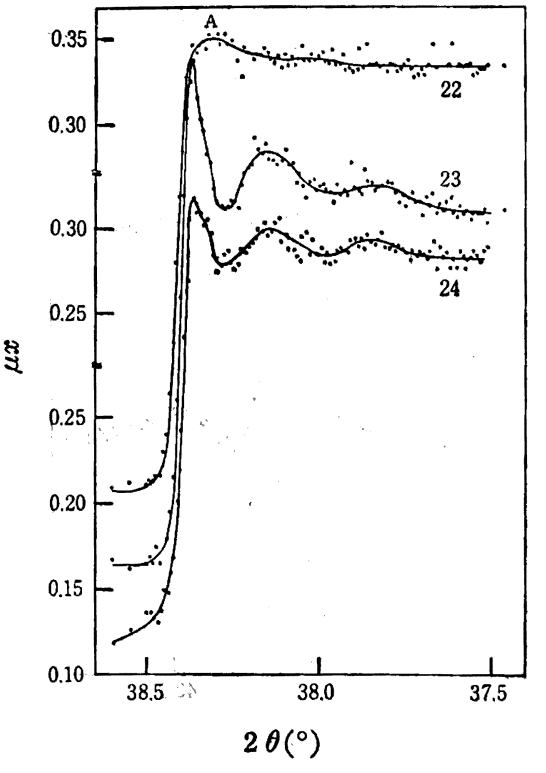

Fig. $12 \mathrm{Br}$ K absorption spectra for $\mathrm{NaBr}$ and $\mathrm{NaBrO}_{3}$ $22: \mathrm{NaBr}, 23: \mathrm{NaBrO}_{3}$ (aqueous soln.), $24: \mathrm{NaBrO}_{3}$ (powder)

Table 2 Energy differences of fine structures of As $\mathrm{K}$ absorption spectra of various substances from the edge of metallic arsenic and photoelectric absorptioncoefficient ratios $\mu_{\mathbf{K}}(\mathrm{A}) / \mu_{\mathrm{K}}(\mathrm{C})$

\begin{tabular}{|c|c|c|c|c|c|c|c|}
\hline \multirow{2}{*}{ Sample } & \multicolumn{6}{|c|}{ Energy differences(eV) } & \multirow{2}{*}{$\frac{\mu_{\mathbf{K}}(\mathrm{A})}{\mu_{\mathrm{K}}(\mathrm{C})}$} \\
\hline & $\mathrm{K}$ & A & B & $\beta$ & C & $\gamma$ & \\
\hline As (metallic), powder & {$[0]$} & 11 & - & 一 & - & 一 & - \\
\hline GaAs, powder & 3 & 12 & $\mathbf{8}_{\mathbf{3}}$ & $12_{3}$ & $14_{4}$ & - & - \\
\hline $\mathrm{As}_{2} \mathrm{O}_{3}$, powder & 3 & 15 & - & 46 & 83 & $13_{3}$ & 1.13 \\
\hline $\mathrm{NaAsO}_{2}$, powder & 4 & 13 & 30 & 46 & 81 & $12_{2}$ & 1.14 \\
\hline $\mathrm{NaAsO}_{2}$, aqueous soln. & 3 & 12 & - & 46 & 83 & $12_{2}$ & 1.33 \\
\hline $\mathrm{As}_{2} \mathrm{O}_{5}$, powder & 8 & 17 & 32 & 52 & 92 & $13_{3}$ & 1.21 \\
\hline $\mathrm{As}_{2} \mathrm{O}_{6}$, aqueous soln. & 7 & 15 & 32 & 53 & 93 & $13_{4}$ & 1.81 \\
\hline $\mathrm{As}_{2} \mathrm{O}_{5}$, ethanol soln. & 6 & 15 & - & 54 & 95 & $13_{6}$ & 1.44 \\
\hline $\mathrm{Na}_{2} \mathrm{HAsO}_{4} \cdot 7 \mathrm{H}_{2} \mathrm{O}$, powder & 8 & 18 & 33 & 52 & 96 & - & 1.27 \\
\hline $\mathrm{Na}_{2} \mathrm{HAsO}_{4}$, aqueous soln. & 6 & 15 & 40 & 53 & 96 & $13_{1}$ & 1.43 \\
\hline $\mathrm{Ca}_{3}\left(\mathrm{AsO}_{4}\right)_{2}$, powder & 7 & 16 & - & 51 & 97 & - & 1.44 \\
\hline $\mathrm{KH}_{2} \mathrm{AsO}_{4}$, powder & 8 & 18 & 38 & 52 & 95 & 148 & 1.22 \\
\hline $\mathrm{PbHAsO}_{4}$, powder & 7 & 15 & 41 & 52 & 94 & $14_{4}$ & 1.39 \\
\hline $\mathrm{As}_{2} \mathrm{~S}_{3}$, powder & 1 & 11 & 25 & 40 & 70 & $10_{4}$ & 1.13 \\
\hline$\left[\mathrm{AsS}_{4}\right]^{3-}$, ammonium polysulfide soln. & 3 & 13 & 31 & 47 & 76 & $12_{2}$ & 1.22 \\
\hline
\end{tabular}

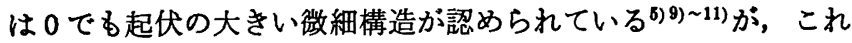
は軽元素では外殼電子の影響が大きいためと思われる。いずれに しても，七素，セレンおよび臭素については微細構造の特徽から， これらの元素の原子価が正であるか，負または0であるかは容易 に判断できることがわかった。

2）吸収端や第 1 ，第 3 吸収ピーク位着は結合原子が同じとき， 原子価が高いほど短波長（高エネルギー）側ヘシフトする傾向が 認められた。吸収端については第 1 系列遷移元素についても同様 の傾向が認められており ${ }^{2)}$ ，このことは多数の元素について一般 的になり立ち，原子価の決定に応用できると考えられる。

3）原子価が同じでも結合原子が異なるときはシフトの程度が

9) C. Sugiura, Y. Fujino, S. Kiyono, Technol. Rep. Tohoku Univ., 33, 199, 205(1968).

10) Y. Fujino, C. Sugiura, S. Kiyono, ibid., 33, 213(1968).

11) C. Sugiura, J.Phys. Soc. Jap., 33, 455(1972).
異なった。すなわち，七素の硫化物では酸化物にくらべ, 吸収端 の化学シフトが小さく，また吸収ピークの間隔が狭くなることが 認められた。これは CuK 吸収スペクトル12)や Co K 吸収スペ

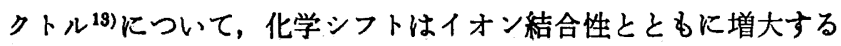
と報告されているのと傾向として一致している。したがって，吸 収端などの化学シフトを原子価の決定に応用するときには，イオ ン結合性す考慮する必要がある。

4）同一物質の粉末試料と溶液試料を比較すると微細構造の各 点の位置にわずかの羑があったものもあるが，系統的な変化は認 められなかった。一方, 第 1 吸収ピークAと第 3 吸収ピークCの $\mathrm{K}$ 殸光電吸収係数の比 $\mu_{\mathrm{K}}(\mathrm{A}) / \mu_{\mathrm{K}}(\mathrm{C})$ は粉末試料よりる水溶液や

12) U.C. Shrivastava, H. L. Nigam, A. N. Vishnoi, Indian J. Pure Appl. Phys., 10, 61(1972).

13) A. K. Dey, B. K. Agarwal, J.Chem. Phys., 59, 1397 (1973). 
Table 3 Energy differences of fine structures of Se $\mathrm{K}$ absorption spectra of various substances from the edge of metallic selenium and photoelectric absorptioncoefficient ratios $\mu_{\mathrm{K}}(\mathrm{A}) / \mu_{\mathrm{K}}(\mathrm{C})$

\begin{tabular}{|c|c|c|c|c|c|c|c|c|}
\hline \multirow{2}{*}{ Sample } & \multicolumn{7}{|c|}{ Energy differences $(\mathrm{eV})$} & \multirow{2}{*}{$\frac{\mu_{\mathbf{K}}(\mathrm{A})}{\mu_{\mathrm{K}}(\mathrm{C})}$} \\
\hline & $\mathrm{K}$ & $A$ & B & $\beta$ & $\mathrm{C}$ & $r$ & $\mathrm{D}$ & \\
\hline Se(metallic), powder & {$[0]$} & 11 & 54 & 72 & 86 & $10_{2}$ & $11_{4}$ & 一 \\
\hline $\operatorname{Se}($ red, $\alpha$-phase), powder & -1 & 10 & 36 & 51 & 75 & $11_{0}$ & $14_{0}$ & 一 \\
\hline CdSe, powder & 2 & 16 & 31 & 49 & 67 & 93 & $11_{2}$ & - \\
\hline $\mathrm{SeO}_{2}$, powder & 3 & 12 & 一 & 49 & 82 & 13 & $19_{2}$ & 1.20 \\
\hline $\mathrm{SeO}_{2}$, aqueous soln. & 3 & 12 & - & 49 & 82 & $14_{2}$ & $20_{1}$ & 1.61 \\
\hline $\mathrm{SeO}_{2}$, ethanol soln. & 3 & 12 & - & 47 & 83 & - & $一$ & 1.37 \\
\hline $\mathrm{H}_{2} \mathrm{SeO}_{3}$, powder & 4 & 16 & 28 & 48 & 82 & - & - & 1.08 \\
\hline $\mathrm{H}_{2} \mathrm{SeO}_{3}$, aqueous soln. & 4 & 14 & - & 48 & 84 & $14_{0}$ & $19_{0}$ & 1.29 \\
\hline $\mathrm{H}_{2} \mathrm{SeO}_{3}$, ethanol soln. & 5 & 13 & - & 50 & 82 & $14_{2}$ & - & 1.50 \\
\hline $\mathrm{Na}_{2} \mathrm{SeO}_{3}$, powder & 4 & 12 & - & 50 & 87 & $14_{1}$ & $20_{0}$ & 1.29 \\
\hline $\mathrm{Na}_{2} \mathrm{SeO}_{3}$, aqueous soln. & 5 & 12 & - & 49 & 83 & $14_{3}$ & $19_{8}$ & 1.51 \\
\hline $\mathrm{K}_{2} \mathrm{SeO}_{s}$, powder & 5 & 14 & 一 & 47 & 84 & $13_{8}$ & $19_{5}$ & 1.27 \\
\hline $\mathrm{K}_{2} \mathrm{SeO}_{3}$, aqueous soln. & 3 & 12 & - & 47 & 83 & $14_{0}$ & $19_{8}$ & 1.36 \\
\hline $\mathrm{Na}_{2} \mathrm{SeO}_{4}$, powder & 7 & 17 & 33 & 52 & 95 & $15_{8}$ & $21_{6}$ & 1.17 \\
\hline $\mathrm{Na}_{2} \mathrm{SeO}_{4}$, aqueous soln. & 8 & 18 & 33 & 53 & 98 & 159 & $21_{7}$ & 1.35 \\
\hline
\end{tabular}

Table 4 Energy differences of fine structures of $\mathrm{Br} \mathrm{K}$ absorption spectra of various substances from the edge of bromine and photoelectric absorption-coefficient ratios $\mu_{\mathrm{K}}(\mathrm{A}) / \mu_{\mathrm{K}}(\mathrm{C})$

\begin{tabular}{|c|c|c|c|c|c|c|c|c|c|}
\hline \multirow{2}{*}{ Sample } & \multicolumn{8}{|c|}{ Energy differences $(e V)$} & \multirow{2}{*}{$\frac{\mu_{\mathrm{K}}(\mathrm{A})}{\mu_{\mathrm{K}}(\mathrm{C})}$} \\
\hline & $\mathbf{K}$ & $A$ & $\alpha$ & B & $\beta$ & $\mathrm{C}$ & $r$ & $\mathrm{D}$ & \\
\hline $\mathrm{Br}_{2}$, lipuid & {$[0]$} & 33 & 55 & $12_{0}$ & - & - & - & - & - \\
\hline $\mathrm{CHBr}_{3}$, liquid & 0 & 17 & 35 & 61 & - & 一 & - & - & 一 \\
\hline $\mathrm{C}_{6} \mathrm{H}_{11} \mathrm{BrN}_{2} \mathrm{O}_{2}{ }^{a}$, powder & 0 & 23 & 38 & 57 & - & - & - & - & - \\
\hline $\mathrm{C}_{27} \mathrm{H}_{28} \mathrm{Br}_{2} \mathrm{O}_{5} \mathrm{~S}^{(b)}$, powder & 0 & 23 & 40 & 58 & - & - & - & - & - \\
\hline $\mathrm{NH}_{4} \mathrm{Br}$, powder & 0 & 39 & - & - & - & - & - & - & 一 \\
\hline $\mathrm{NaBr}$, powder & 0 & 39 & - & - & 一 & - & - & 一 & - \\
\hline $\mathrm{KBr}$, powder & 1 & 32 & - & - & - & 一 & - & - & - \\
\hline $\mathrm{NaBrO}_{3}$, powder & 4 & 17 & 一 & - & 48 & 92 & $15_{1}$ & $19_{6}$ & 1.06 \\
\hline $\mathrm{NaBrO}_{3}$, aqueous soln. & 3 & 17 & 一 & - & 48 & 92 & $15_{8}$ & $20_{5}$ & 1.23 \\
\hline $\mathrm{KBrO}_{3}$, powder & 3 & 17 & - & - & 47 & 95 & $15_{0}$ & $20_{1}$ & 1.09 \\
\hline $\mathrm{KBrO}_{3}$, aqueous soln. & 3 & 16 & 一 & - & 50 & 92 & $15_{8}$ & $21_{7}$ & 1.24 \\
\hline $\begin{array}{l}\text { a) } \alpha \text {-Bromoisoval } \\
\text { b) Bromothymol }\end{array}$ & $\begin{array}{l}\text { lcarba } \\
\left(3,3^{\prime}\right.\end{array}$ & $\begin{array}{l}\text { ide. } \\
\text { ibror }\end{array}$ & thy & olsul & apht & lein & & & \\
\hline
\end{tabular}

エタノール溶液試料で大きくなる傾向が認められた。これについ ては従来の測定例が少なく十分な比較はできないが, Van Nordstrand $^{8)}$ による $\mathrm{K}_{8}\left[\mathrm{Co}(\mathrm{CN})_{6}\right]$ の $\mathrm{Co} \mathrm{K}$ 吸収スペクトルデータか ら計算してみると, $\mu_{\mathrm{K}}(\mathrm{A}) / \mu_{\mathrm{K}}(\mathrm{C})$ は粉末で 0.90 , 水溶液で 1.00 であったので, この傾向と一致している。このような傾向を示す 理由は明らかでないが，第 2 近接原子の影響と考えられる。この ことはヒ素の複合酸化物の吸収スペクトルにおいて, 測定元素以 外の陽イオンがアルカリ金属イオンの場合と $\mathrm{Ca}^{2+}$ また $\mathrm{Pb}^{2+}$ の場合とで, $\mu_{K}(\mathrm{~A}) / \mu_{\mathrm{K}}(\mathrm{C})$ が大きく変化したことからも理解で きる。すなわち， $\mu_{\mathrm{K}}(\mathrm{A}) / \mu_{\mathrm{K}}(\mathrm{C})$ は第 2 近接原子の影響を受けや すいと考えられる。
以上のようにヒ素, セレンおよび臭素の $\mathrm{K}$ 吸収スペクトルの钘 細構造は測定元素の結合状態，とくに測定元素の原子価とそれが 結合している原子によって大きく変化することがわかった。この ことの状態分析への応用については次報以降で報告の予定であ る。

終りに GaAs の試料をご提供いただいた本学助教授国谷保婎氏， ならびに実験に協力された当研究室学生宮尾徹, 小松辰音の両 君に感謝します。また, 本研究の費用の一部は文部省科学研究費 によった。付記して謝意を表します。

（1973 年 10 月, 第 10 回 X線分析討論会(一部)発表) 


\title{
Fine Structures of X-Ray K-Absorption Spectra of Arsenic, Selenium and Bromine ${ }^{\dagger}$
}

\author{
Masaaki Iwatsuki and Tsutomu Fukasawa \\ Department of Applied Chemistry. Faculty of Engineering, \\ Yamanashi University; Takeda, Kofu-shi 400 Japan
}

$\mathrm{X}$-ray $\mathrm{K}$-absorption spectra of arsenic, selenium and bromine in the states of simple substances and various compounds have been measured in order to apply the $\mathrm{X}$-ray $\mathrm{K}$-absorption spectroscopy to the chemical state analyses of these elements. An X-ray diffractometer with a molybdenum-target tube was used in the ordinary arrangement for diffraction experiment, except setting a topaz analyzing crystal at the center of its goniometer. Sample mounting to the apparatus was done with the following techniques. A powder sample was mixed in white vaseline by use of a thin spatula, and was uniformly spreaded on a $6 \mu$-Mylar film. Aqueous and ethanol solution samples were placed in a Mylar-window cell (Fig. 1). Bromine and bromoform samples were placed in a. Teflon-window cell (Fig. 2). The sample was placed between a divergence slit and the analyzing crystal, and was measured under the experimental condition of Table 1.

The absorption spectra of these elements in oxides and sulfides had pronounced fine structures at the short-wavelength side of the absorption edges. On the contrary, the spectra of the elements in zero or negative valence state had small undulations. The wavelengths of the absorption edge and peaks shifted to shorter side as the valence of the absorbing element became higher. The energy differences between the absorption peaks of arsenic sulfides were smaller than those of arsenic oxides. A K-photoelectric absorption-coefficient ratio of the first absorption peak to the third peak of a powder sample was smaller than that of aqueous or ethanol solution sample. Details of an observed absorption spectrum, especially height and wavelength of the first absorption peak, depended upon the thickness of sample. Therefore, reasonably thin sample was required in order to obtain an accurate spectrum.

$\dagger$ Study on the State Analysis by Use of X-Ray Absorption Spectra. I. 